\title{
STRATEGI PENGEMBANGAN MAKANAN TRADISIONAL BERBASIS TEKNOLOGI INFORMASI SEBAGAI UPAYA PELESTARIAN SENI KULINER BALI
}

\author{
Cokorda Istri Raka Marsiti ${ }^{1,}$ Ni Made Suriani $^{2}$, Ni Wayan Sukerti ${ }^{3}$ \\ Fakultas Teknik dan Kejuruan,Universitas Pendidikan Ganesha \\ Email: ${ }^{1)}$ Cokorda@Undiksha.ac.id ${ }^{2}$ Surianimade@yahoo.com \\ ${ }^{3)}$ Wayansukerti71@yahoo.com
}

\begin{abstract}
Abstrak
Tujuan penelitian ini adalah (a) melakukan penelusuran literatur dan menggali pengalaman tim peneliti terkait jenis-jenis hidangan tradisional khas Bali, (b) melakukan uji coba resep-resep sehingga diperoleh resep-resep baku, dan (c) membuat situs Website tentang hidangan tradisional khas Bali dilanjutkan dengan mengunggah semua resep.

Penelitian ini penelitian survey dilanjutkan dengan eksperimen dengan metode pengumpulan data melalui observasi dan uji panelis untuk menilai kualitas produk,sesuai klasifikasinya yaitu makanan pokok, lauk-pauk, sayuran, jajanan, dan minuman. Responden dalam penelitian ini adalah dosen Jurusan PKK.

Hasil penelitian menunjukkan bahwa kajian terhadap resep-resep yang telah teridentifikasi pada penelitian menghasilkan resep-resep baku hidangan tradisional Bali.Selanjutnya,hasil uji panelis sebagai berikut. (1)Kualitas makanan pokok khas Bali, dengan kategori baik meliputi: nasi tulen putih, nasi tulen merah, nasi kuning Bali, nasi moran sele bun, moran keladi, moransele sawi, moran biu, bubuh moreng, mengguh, ketupat, belayag, entil dan pesor; (2) Kualitas lauk-pauk dengan kategori baik meliputi: urutan be celeng, lawar merah, lawar putih, tum ayam, pesan cakep, gerangasem, ayam betutu, tum be celeng, sate empol;(3) Kualitas hidangan sayuran dengan kategori baik meliputi:jukut ares, jukut balung nangka, jukut plecing gonda, plecing kangkung, kalas kacang panjang,urab paku, serombotan; (4) Kualitasjajanan khas Bali dengan kategori baik meliputi: jaja bantal, jaja sumping waluh, klepon;(5)Kualitas minuman khas Bali dengan kategori baik meliputi: es rujak kuud, es daluman, rujak uyah sera tabya,dan rujak manis. Selanjutnya semua resep yang telah dihasilkan ini diunggah ke website dengan akun: http://cokistrirakamarisiti.com.
\end{abstract}

Kata Kunci: Pengembangan, Seni Kuliner Bali,Strategi 


\section{PENDAHULUAN}

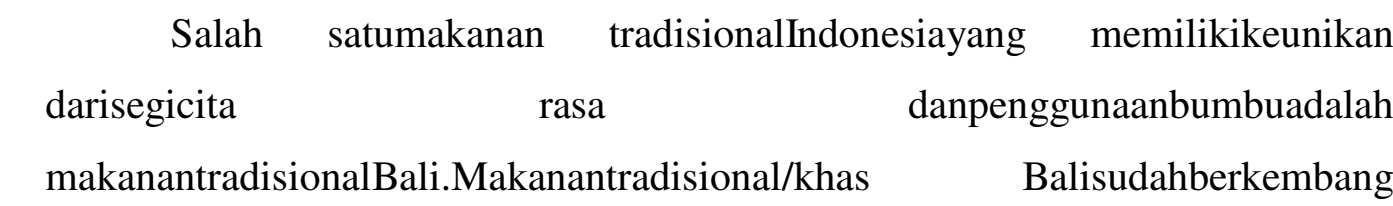
sejakmasuknya AgamaHindudiBali,merupakan suatu tradisi yang diwariskan secara turun-temurun (Garjito,M.dkk.2017:223). Kuliner Bali senantiasa berkembang seiring kemajuan diberbagai bidang kehidupan, namun masih tetap mempertahankan keunikannya, dengan berlan-daskan konsep Tri Hita Karana. Artinya, bahwa bahan dan makanan yang dibuat tidak hanya untuk dikonsumsi, namun juga untuk persembahan kepada Tuhan (Parahyangan) sebagai wujud syukur atas karunia-NYA, lalu untuk dikonsumsi masyarakat (Pawongan) untuk memenuhi kebutuhan jasmani, dan juga bahan yang digunakan diambil dari lingkungan setempat (Palemahan) untuk menjaga lingkungan yang harmoni.

Dengan semakinberkembangnyawisataminat khusus (wisatakuliner) dan kemajuan dewasa ini, apalagi Bali sebagai destinasi wisata di dunia,sudahpatutdisuguhkanmenu makanantradisionalBali.Mereka akan menikmatisuguhan denganjenis olahan, jenismakanan, jenispenghidangan danjenis bumbu(basa) dan rasayangsangatunik,sehingga dapatmemberikankepuasanterhadap rasadankebutuhangastronomimerekadanmenjadikenangansehinggatujuanmereka ke Balibukansajakarenakeindahanalam,namunjugakarenakulinariyang mempesona danberagam.Namundemikian,kenyataanyangadasekarang inijustrumakanan tradisional Balitidak begitu banyak disajikan di industrihotel dan restoran.

Belumbanyakrestorantradisionalyang khususmenyajikanmasakanmasakan khas tradisional Bali, hal ini disinyalir kurangnya informasi mengenai khasanah masakan bali, terbatasnya buku-buku resep masakan khusus masakan khas Bali, sehingga tidak setiap orang mampu menyajikan menu masakan khas Bali. Masakan atau makanan khas Bali memiliki kekhasan tersendiri, seperti perpaduan bumbu yang tanpa takaran mampu menghasilkan komposisi bumbu yang kaya rasa,yang umumnya dikerjakan oleh laki-laki sebagai juru 
patus/tukang lawar.(Suandra, 1972).

Selain itu, masakan tradisional khas Bali kurang diminati oleh kalangan anak-anak maupun remaja. Hal ini disebabkan oleh semakin menjamurnya resto-resto cepat saji, kedai-kedai yang menjual makanan fusion atau modifikasi, yang lebih disukai oleh kalangan muda. Jika kondisi ini dibiarkan, maka dapat berakibat pada punahnya hidangan tradisional Bali, yang merupakan warisan leluhur secara turun- temurun, yang merupakan salah satu asset budayayang perlu dilestarikan.

Terbatasnya sumber pengetahuan tentang resep makanan khas Bali berupa buku-buku resep menyebabkan penulis tertarik untuk mengangkat permasalahan ini menjadi sebuah penelitian, dengan mengadopsi perkembangan teknologi dan informasi yang sangat pesat saat ini.Penelitian ini merupakan sebuah strategi pengembangan makanan khas Bali berbasis teknologi informasi.Maksudnya adalah resep-resep yang diwariskan secara turuntemurun,peneliti kumpulkan, dilakukan identifikasi resep-resep, uji coba resep.Selanjutnya berdasarkan resep baku, peneliti menyusun ke dalam buku, dan juga media berupa web site khusus resep makanan khas Bali.

Upayapelestariansenikulinertidak hanyaterbataspada penyelenggaraan berbagai festival makanansaja yanghanyaberlangsungbeberapahari.Namun,bagaimana strategi memasyarakat-kankulinersebagaisebuahkewajiban bagi masyarakat Balihampirbelumtampakpelaksana-annya.Dengan kemajuan IPTEK seperti saat ini, yang mana kaum muda Bali mulai anak-anak sampai remaja sangat jarang menyukai makanan maupun minuman tradisonal khas Bali.Mereka cenderung menyukai makanan maupun minuman cepat saji semacam frenchcise, disamping menawarkan cepat saji, enak, dan tentunya meningkatkan status. Jika kondisi ini terjadi secara terus-menerus, niscaya makanan tradisional khas Bali yang merupakan warisan leluhur akan punah, dan Bali akan kehilangan identitas terutama keunikan kuliner yang tidak bisa lepas dari budayanya. (Marsiti, 2005).

Dengan demikian, sebagai generasi penerus dari warisan leluhur Bali, peneliti memiliki kewajiban untuk mensosialisasikan hidangan-hidangan tradisional khas Bali mulai makanan pokok, lauk-pauk, sayur/sayuran, jajanan maupun minuman, dengan mensinergikan melalui pemanfaatan teknologi informasi yakni resep-resep 
makanan tradisional Bali berbasis website. Harapannya, masyarakat Bali khususnya anak-anak dan remaja sebagai bagian yang peka terhadap teknologi mampu mengakses berbagairesep makanan tradisional khas Bali selanjutnya dicoba, dinikmati, dandisukai. Dengan demikian, seni kuliner Bali akan berkembang, ajeg, dan lestari sebagai bagian dari budaya Bali.Hal ini sejalan dengan pendapat (Okech.Roselyne, 2014)bahwa salah satu komponen kunci dari hubunganantaramakanan dan pariwisata adalah bahwa promosi makanan tradisional.

Strategi pengembangan makanantradisional khas Bali berfungsi untuk mengembalikanatau memperkenalkankembalitentangjenis-jenismakanan tradisionalBali yang merupakanwarisanleluhursecaraturun-temurun. Pendaftaranataupengelompokan kembaliberagam jenis makanan tradisional Bali yang disosialisasikan melalui media internet dimaksudkanagar makanantradisionalBali tersebut ajeg,tidak tergerus arus modernisasi, dandapat diwarisi olehgenerasi berikutnya.

Dalamproses pengolahan makanan mulai daripersiapan(pembersihanatau pencucian)sampai penataanhidangan hendaknya atau wajibmemperhatikan kebersihanatauhygienedansanitasiserta nilaigiziyangterkandung.Begitujuga padawaktumemasak agarmemperhatikan temperature yangtepatdansesuai agar tidakgosongdantidakbanyakkehilangan vitamin.Selainitu,dalampenyimpanan makananjugaharusdiperhatikantemperaturnya.Bilatidaksesuai makamakanan akancepatbasi ataumengandung bakteriyang membahayakan kesehatan manusia.Dengandemikian,dalampengolahanmakananbanyakmelibatkanilmu pengetahuan,antaralain ilmugizi,fisika, higienedansanitasi sertayanglainya.

Suci mengemukakan batasanmengenai makanankhassuatu daerahtermasukBali adalahmakananyang dijumpaidandiolah,dihidangkandan dimakansecara berkelanjutandarigenerasikegenerasi dan berbedadari makanandaerahlainnya(Marsiti, 2005).

\section{METODE}

Jenispenelitian iniadalah penelitian survei dilanjutkan dengan eksperimen yaitupenelitianyang mendalamtentang senikulinerBali dengan sengaja 
menimbulkan

variabel.Dalampelaksanaannya,penelitianinidapatditinjaudaritujuannyayaitumeng galidanmemahamisecara luashidangan Tradisional khas Bali. Kesimpulan yang diperolehpada penelitiansurvei berlakusecaraterbatas hanyapada objek yang ditelitiyaitu hidangan khas Bali. Penelitianini dilaksanakan di Laboratorium Jurusan PKK, dan studi literatur dengan menggunakanteknik purposive.Lokasiini dipilih atas dasar pertimbangan (1) Jurusan PKK (Tata Boga) memiliki lab. produksi yang representatif untuk melakukan uji coba resep,(2) ekspert atau ahli yang digunakan dalam menilai makanan standar terdiri atas para dosen PKK (bidang Boga).

Metode analisisdatayang digunakan dalampenelitianini adalahanalisisdeskriptif kualitatif.

\section{HASIL DAN PEMBAHASAN}

Melalui uji panelis diperoleh hasil uji kualitas secara umum dapat dinyatakan sebagai berikut. (1) Kualitas makanan pokok yang telah diuji melalui organoleptic diperoleh hasil dalam kategori baik sesuai kreteria yaitu rasa, tekstur, maupun penampilan. (2) Kualitas hidangan lauk-pauk secara umum dalam kategori baik, hanya disarankan untuk penggunaan bumbu yang lebih tajam (sepek),sehingga benar-benar mencirikan makanan khas Bali. (3) Kualitas hidangan sayur maupun sayuran juga dalam kategori baik, denganbeberapa saran seperti jukut nangka kebanyakan kunyit, namun dari aspek rasa bumbu sudah baik. (4) Kualitas jajanan dalam kategori baik, tetapi dari segi bentuk lebih ditingkatkan terutama pada jaja bantal yang kebesaran untuk porsi satu orang. (5)Kualitas minuman dalam kategori baik, mencirikan kekhasan minuman tradisional Bali termasuk rujak buah.

Resep-resep yang telah diuji coba dan dinilai oleh panelis, selanjutnya dibuat Website sebagai media untuk mengunggah resep-resep hidangan tradisional Bali mulai dari makanan pokok, lauk-pauk, sayuran, jajanan, dan minuman. Website yang dibuat nantinya bisa diakses oleh masyarakat secara luas, dengan nama akun: http://cokistrirakamarsiti.com. Melalui website hidangan khas Bali akan dikenal luas oleh masyarakat dan yang terpenting juga bagi anak-anak, 
remaja, mulai tertarik dengan hidangan Balisupaya melekat dengan budaya sendiri, serta secara tidak langsung bisa dipraktikkan dan menjadi menu dalam lingkungan keluarga. Hal ini sejalan dengan pendapat (Ariani, 2017) bahwa seni kuliner Bali merupakan salah satu seni yang harus dilestarikan, karena pada kenyataannya sudah semakin jarang dibuat oleh ibu rumah tangga yang bertanggungjawab menyajikan hidangan-hidangan utnuk menu sehari-hari. Hal ini disebabkan oleh berbagai faktor seperti saat ini ibu rumah tangga dituntut berperan ganda sebagai pengelola rumah tangga dan juga sebagai pekerja. Disamping itu,ada beberapa alasan ibu rumah tangga jarang memilih kuliner tradisional untuk disajikan yaitu: merepotkan karena banyak bumbunya, pengolahannya lama, dan anak-anak kurang menyukai. Hal ini sebagai akibat atau dampak dari modernisasi dan globalisasi, kepraktisan membeli makanan cepat saji, sehingga kondisi ini jelas sangat mengkhawatirkan karena generasi muda dari waktu ke waktu akan melupakan hidangan tradisional.Hasil penelitian (Sukerti, Marsiti, \& Suriani, 2016) tentang pengelompokan makanan khas Buleleng diperoleh beraneka ragam makanan khas tiap kecamatan yang bisa diangkat menjadi suatu hidangan yang layak dijual, dimana makanan khas tersebut menggunakan bahan-bahan alami setempat yang jarang ditemui didaerah lain.

(Margi, dkk. 2013) menyatakan bahwa terbentuknya cara pandang masyarakat modern tentang cara pengolahan hidangan tradisional dianggap kurang efisien dan menghabiskan waktu lamasehingga resep-resep tradisional yang diwariskan secara turun-temurun dari nenek moyang sudah banyak mengalami perubahan, bahkan sebagian hidangan tradisioanal sudah tidak dikenal oleh generasi muda saat ini. Kenyataan menunjukkan walaupun masakan khas Bali sudah dijual di resto-resto yang ada di daerah Bali, namun belum mampu menjadi salah satu Ikon Pariwisata Bali.Hal ini disinyalir disebabkan oleh penggunaan bumbu segar yang tajam, (bahasa Bali, sepek), belum mampu diadaptasi oleh masyarakat luar daerah Bali maupun mancanegara. Hal ini menjadi tantangan bagi masyarakat yang respek terhadap perkembangan hidangan tradisional khas Bali, untuk melakukan inovasi, modifikasi, diversifikasi hidangan Bali tanpa menghilangkan kekhasan daerah Bali(Sirtha, 1998). 
Pada konteks kuliner ini, Bali memiliki keunikan dari cara pengolahan hingga penyajiannya yang bisa memiliki nilai jual tinggi. Bumbu yang ramah lingkungan yakni bumbu-bumbu yang digunakan berasal dari hasil produksi pertanian masyarakat Bali tanpa pengawet makanan dan tanpa bahan tambahan dari bahan jadi yang sudah ada dipasar, pada akhirnya mampu menghasilkan cita rasa yang lezat, gurih dan khas. Selain itu, cara pembuatannya yang menggunakan peralatan yang masih tradisional juga mampu menghasilkan aroma masakan yang sedap, sehingga beberapa tempat makan ada yang sengaja menggunakan peralatan masak tradisional sebagai daya tarik bagi wisatawan. (Widiastini, dkk. 2014). Hal ini sejalan dengan (Everett \& Aitchison, 2008) bahwa peran wisata kuliner dalam meningkatkan pengeluaran wisatawan, sangat penting dalam kerangka keberlanjutan kuliner Bali. Selain itu, hasil penelitian(Pieniak Z, 2009) bahwa.Model yang diusulkan berkontribusi pada pemahaman faktor-faktor yang membentuk citra dan mempengaruhi konsumsi makanan tradisional di Eropa secara lebih baik. Sikap umum terhadap makanan tradisional, keakraban, dan pentingnya kealamian makanan muncul sebagai penggerak konsumsi makanan tradisional.

\section{PENUTUP}

Berdasarkan hasil penelitian dan pembahasan yang telah diuraikan di atas, maka dapat disimpulkan sebagai berikut. (1)Resep-resep makanan pokok khas Bali yang telah diuji coba dan diuji oleh ekspert, menunjukkan hasil dengan kategori baik yang meliputi: nasi tulen, nasi tulenmerah, nasi kuning Bali, nasi moran sele bun,moran keladi, moran sele sawi, moran biu, bubuh moreng, mengguh, ketupat, belayag, entil dan pesor; (2) Hidanganlauk-pauk khas Bali menunjukkan hasil dengan kategori baik yang meliputi: urutan be celeng, lawar merah, lawar putih, tum ayam, pesan cakep, gerangasem, ayam betutu, tum be celeng, dansate empol;(3)Hidangan sayuran khas Bali menunjukkan hasil dengan kategori baik yang meliputi: jukut ares, jukut balung nangka, jukut plecing gonda, plecing kangkung, kalas kacang panjang,urab paku, serombotan;(4) Hidanganjajanan khas Bali menunjukkan hasil dengan kategori baik yang meliputi: jaja bantal, jaja sumping waluh,dan klepon;(5) Resep-resep minuman 
khas Bali, menunjukkan hasil dengan kategori baik yang meliputi: es rujak kuud, es daluman, rujak uyah sera tabya, dan rujak kuah pindang.

Penelitian ini terbatas pada klasifikasi hidangan tradisional Bali dari makanan pokok, lauk-pauk, sayuran, jajanan, dan minuman. Sedangkan makanan pendamping maupun pelengkap, dan juga makanan pada kesempatan khusus belum diteliti. Oleh karena itu, disarankan kepada peneliti lain untuk melanjutkan penelitian ini sesuai jenis hidangan dimaksud.

\section{DAFTAR RUJUKAN}

Ariani, R. P. (2017). Mengenal Kuliner Bali (1st ed.). Pt.Rajagrafindo Persada.

Everett, S., \& Aitchison, C. (2008). The Role of Food Tourism in Sustaining Regional Identity: A Case Study of Cornwall, South West England. Journal of Sustainable Tourism. https://doi.org/10.2167/jost696.0

Gardjito,M.dkk. 2017.Kuliner Indonesia (Profil Struktur, Bumbu, dan Bahan). Yogyakarta. Gajah Mada University Press.

Margi, I.K, Ariani, R, P, Widiastini, N.M.A, Suriani, N. M. (2013). Identifikasi Potensi Wisata Kuliner Berbasis Bahan Baku Lokal di Bali. Ilmu Sosial dan Humaniora, 2(2).

Marsiti, C. I. R. (2005). Hidangan Bali (p. 15). Singaraja.

Okech.Roselyne, N. (2014). Developing Culinary Tourism: The Role of Food as a Cultural Heritage in Kenya. Confrence of Global Busness. https://doi.org/978-1-941505-14-4

Pieniak Z. (2009). Association between traditional food consumption and motives for food choice in six European countries. Elsevier. https://doi.org/doi:10.1016/j.appet.2009.05.019

Sirtha, I. (1998). Aspek Budaya Makanan Tradisional Bali dalam Menunjang Program Pariwisata. Dinamika Kebudayaan, 1.

Suandra. (1972). Dharma Caruban (Tuntutan Ngebat). Denpasar : CV Kayumas Agung. Suci, dkk. 1986 Pengolahan Makanan. denpasar: CV Kayu Mas.

Sukerti, Ni Wayan, Marsiti, C. I. R., \& Suriani, Ni Made. (2016). Kajian tentang Makanan Tradisional Buleleng sebagai Upaya Pelestarian Seni Kuliner Bali. Prosiding Senari4.

Widiastini, A. N. ., Ariani, R. ., \& Andiani, D. . (2014). Pengemasan Makanan Lokal Sebagai Produk Wisata Kuliner Di Bali. Jurnal STP Trisakti. 